\title{
Two-dimensional gel electrophoresis of Mytilus galloprovincialis: differences in protein expression between intertidal and cultured mussels
}

\author{
J. L. López ${ }^{1, *}$, E. Mosquera ${ }^{1}$, J. Fuentes ${ }^{2}$, A. Marina ${ }^{3}$, J. Vázquez ${ }^{3}$, G. Alvarez ${ }^{1}$ \\ ${ }^{1}$ Departamento de Biología Fundamental, Facultad de Biología, Universidad de Santiago de Compostela, \\ 15782 Santiago de Compostela, Spain \\ ${ }^{2}$ Centro de Investigaciones Mariñas, Consellería de Pesca, Xunta de Galicia, 36620 Pontevedra, Spain \\ ${ }^{3}$ Centro de Biología Molecular Severo Ochoa, CSIC Universidad Autónoma de Madrid, 28049 Madrid, Spain
}

\begin{abstract}
Two-dimensional gel electrophoresis (2-DE) is a unique method of large-scale protein characterisation, and is a powerful approach in the study of protein expression. In the present work, the experimental conditions for 2-DE of foot proteins from the mussel Mytilus galloprovincialis Lmk were established; the technique was performed with intertidal and cultured mussels using Melanie 3 software for data analysis. This powerful technique enabled the visualisation of a total of 750 protein spots consistently expressed in the foot. The intensity of 92 selected spots was compared between intertidal and cultured mussels, and statistically significant differences were detected in the expression of $45(48.9 \%)$ of the 92 proteins analysed. In 31 of these proteins, intensity was higher in the cultured stock than in the intertidal mussels, while in 14 proteins spot intensity was higher in the latter. Using mass spectrometry (MS) combined with sequence database searching, 6 of the most prominent differentially expressed proteins were analysed. Of these, 1 was identified as being Heat-shock Protein 70, and 2 were shown to be cytoskeleton-associated proteins, myosin and actin. Heat-shock Protein 70, which is known to be involved in cellular transport and chaperoning and associated with stress situations, was more highly expressed in intertidal mussels living in littoral areas than in cultured mussels. These findings are discussed in connection with the molecular changes involved in the adaptation of mussels to different ecological conditions.
\end{abstract}

KEY WORDS: Mytilus galloprovincialis - Two-dimensional gel electrophoresis $\cdot$ Proteome $\cdot$ Foot proteins Resale or republication not permitted without written consent of the publisher

\section{INTRODUCTION}

High-resolution 2-dimensional gel electrophoresis (2-DE), first developed by O'Farrell (1975), is a powerful and sensitive technique for analysing complex protein mixtures. 2-DE has been developed as a method for protein separation combining isoelectric-focusing gel electrophoresis (IEF) with sodium dodecyl sulfate (SDS) polyacrylamide gel electrophoresis (PAGE). When the resulting protein patterns are studied using computer-

\footnotetext{
*E-mail: jllopez@usc.es
}

assisted programs, the technique becomes a unique method for the qualitative and quantitative analysis of protein expression. Furthermore, in recent years the identification of 2-DE-separated proteins has been improved with the development of highly sensitive protein-sequencing and mass spectrometric methods (MS) (Humphery-Smith et al. 1997, Hochstrasser 1998). The applications of 2-DE are numerous, particularly, in the context of proteomic studies (Anderson \& Anderson 1998, Jungblut et al. 1999). For example, for detecting and quantifying modifications in genome expression during development, under different stresses, or in response to different environmental conditions. 
In this article, the experimental conditions for performing 2-DE of tissues from the mussel Mytilus galloprovincialis are established. Our findings show that 2-DE can detect alterations in protein expression between 2 mussel populations, intertidal and cultured, living under 2 different ecological conditions. Furthermore, this investigation also allowed us to identify the more significant quantitative protein changes between these 2 populations. This work is the first time that 2-DE has been applied to this mussel, which is of great commercial interest (Pérez Camacho et al. 1991, Hickman 1992) and is a member of the worldwide-distributed genus Mytilus. It plays a prominent ecological role in structuring temperate rocky-shore communities (Suchanek 1985), and is considered a 'sentinel' in environmental monitoring programs of estuarine and coastal areas (see the 'Mussel Watch' concept in Goldberg 1975).

\section{MATERIALS AND METHODS}

Mussel sampling. Mussels from the NW coast of the Iberian Peninsula belong to the Mytilus galloprovincialis Lmk form (Sanjuan et al. 1990, 1994). In November 1998, adult mussels were collected from 2 different environments: a raft-cultured population in an inner cultivation area in the Ría de Arosa (NW coast of the Iberian Peninsula), and a mid-intertidal population in a wave-exposed rocky shore in the same region. Mussels in each of the 2 environments are exposed to very different physical (temperature, desiccation and turbulence) and ecological (food availability and predation) conditions. While mussels from the raft-cultured population are permanently submerged in a sheltered and food-rich environment with water temperatures ranging from $12^{\circ} \mathrm{C}$ in winter to $19^{\circ} \mathrm{C}$ in summer (Fuentes et al. 2000), mussels from the wave-exposed mid-intertidal population withstand daily periods of aerial exposure during which feeding is impeded and temperature reaches extreme values of near $0^{\circ} \mathrm{C}$ in winter and $30^{\circ} \mathrm{C}$ in summer (Fuentes unpubl. data). The sampled mussels were transported live to the laboratory, where they were dissected. The foot of each mussel was frozen and lyophilised, and then stored at $-70^{\circ} \mathrm{C}$ until electrophoresis.

Protein extraction. Proteins were extracted by suspending $30 \mathrm{mg}$ of lyophilised tissue inmediately in O'Farrell lysis buffer (9.5 M urea, 2\% NP-40 [w/v], $2 \%$ ampholytes, ph 7 to 9 , and $100 \mathrm{mM}$ dithiothreitol [DTT]) to avoid proteolysis. Proteins were solubilised for $3 \mathrm{~h}$ at $30^{\circ} \mathrm{C}$ with vigorous shaking, using a thermomixer shaker (Eppendorf). The mixture was centrifuged at $12000 \times g$ for $15 \mathrm{~min}$. Supernatants were either used immediately for electrophoresis or were stored at $-70^{\circ} \mathrm{C}$. Protein concentration was measured according to the method of Bradford (1976) with modifications (Ramagli \& Rodríguez 1985).

Two-dimensional gel electrophoresis. 2-DE was performed as described by O'Farrell (1975) with minor modifications (Santarén \& García-Bellido 1990). The first-dimensional isoelectric-focusing gels (IEF) for resolving proteins with isoelectric points (pI) ranging from 4 to 7.5 were run in $180 \times 1.5 \mathrm{~mm} 4 \% \mathrm{w} / \mathrm{v}$ polyacrylamide tube gels containing $2 \%$ ampholytes $(1.6 \%=\mathrm{pH} 5$ to $7 ; 0.4 \%=\mathrm{pH} 3.5$ to 10$)$. Protein loads of $50 \mu \mathrm{g}$ were applied to each gel and then focused at $200 \mathrm{~V}$ for $2 \mathrm{~h}, 500 \mathrm{~V}$ for $2 \mathrm{~h}$ and finally $800 \mathrm{~V}$ for $16 \mathrm{~h}$. Gels were equilibrated for $10 \mathrm{~min}$ with $100 \mathrm{mM}$ DTT, $2 \% \mathrm{w} / \mathrm{v} \mathrm{SDS}, 0.06 \mathrm{M}$ Tris base, $\mathrm{pH}$ 6.8, and stored frozen at $-80^{\circ} \mathrm{C}$ until application of second-dimension SDS-PAGE gels $(12 \% \mathrm{~T}, 2.6 \% \mathrm{C}, 200 \times 160 \times 1.5 \mathrm{~mm})$. Second-dimension electrophoresis was carried out at $25 \mathrm{~mA}$ per gel for $1.5 \mathrm{~h}$ followed by $35 \mathrm{~mA}$ per gel for $5 \mathrm{~h}$. Protein spots in gels were visualised by the silver-staining technique of Morrissey (1981). Preparative gels for mass spectrometric analysis were silverstained, avoiding the glutaraldehyde.

Computer analysis of 2-DE patterns. Silver-stained 2 -DE gels were digitised at $84.7 \times 84.7 \mu \mathrm{m}$ resolution using a Bio-Rad GS-700 imaging densitometer. Protein patterns were analysed using Melanie 3 software (BioRad). Protein spots were analysed without filtering images to avoid artificial effects on images when comparisons were made. Spots detected by the program were matched between each gel in each group. Protein spots were characterised with respect to their apparent molecular mass (Mr) and pI with 2-D SDS-PAGE standards (Bio-Rad). Mr and pI values were automatically calculated for the remaining protein spots by Melanie 3 software. Intensity levels of the spots were normalised by expressing the intensity of each protein spot in a gel as a proportion of the total protein intensity detected for the entire gel (relative volume, \%vol) (Byrjalsen et al. 1999, Tsuji et al. 1999). Normalised protein-intensity data for all studied spots were exported from the Melanie 3 software to the SPSS statistical package for analysis. Comparison between gels is based on matrix plots and correlation coefficients. Matrix scatter plots are a graphical representation of the correlation matrix, with each panel showing the relevant scatter diagram.

Mass spectrometric protein identification. The spots of interest were excised and subjected to in situ digestion with trypsin as described by Svechenko et al. (1996). A small aliquot $(0.5 \mu \mathrm{l})$ of the extract was taken up and analysed by matrix-assisted laser desorption ionisation/time-of-flight (MALDI-TOF) mass spectrometry. Gel extracts were pooled, dried down, resuspended in $10 \mu \mathrm{l}$ of $0.1 \%$ trifluoroacetic acid (TFA) and subjected to automated desalting by a procedure based on that of Konecny \& Redinbaugh (1997). 
Analyses by MALDI-TOF mass spectrometry were performed using a Kompact Probe instrument (KratosShimazdu, Manchester, UK), equipped with an extended flight tube of $1.7 \mathrm{~m}$ and delayed extraction, operating in linear mode. Of the fractions to be analyzed, $0.5 \mu \mathrm{l}$ was applied to the target and dried out; $0.5 \mu l$ of saturated $\alpha$-cyano-4-hydroxycinnamic acid matrix in water:acetonitrile (1:1) containing $0.1 \%$ TFA was then added and dried out. External calibration was carried out with a set of synthetic peptides.

Analysis by nanoelectrospray ion trap (nESI-IT) was performed using an ion-trap mass spectrometer, Model LCQ (Finnigan, ThermoQuest, San Jose, California, USA) equipped with a nanospray interface, exactly as described previously (Marina et al. 1999). De novo sequencing of peptides was performed by multiple subfragmentation (MSn) steps (Marina et al. 1999), which help to determine the nature of the fragmentation series.

The proteins in the spots were identified from the peptide mass fingerprints obtained by MALDI-TOF using MASCOT, MS-FIT, Protein Prospector, or other suitable software packages. A protein was considered as a positive match when it ranked first position in different searching engines. Protein identification was confirmed by MS/MS spectra from at least 1 peptide, obtained by nESI-IT. The MS/MS spectra were used for database searches using the Pepsearch or Sequest programs (Finningan, ThermoQuest), and employing the non-redundant Fasta database. Alternatively, MS/MS spectra were manually interpreted, and the obtained sequences were used for an homology search using the program FASTA (University of Wisconsin, Madison, WI, USA).

\section{RESULTS}

\section{Overall pattern of protein expression}

Fig. 1 shows a representative 2-DE gel of foot proteins from Mytilus galloprovincialis. The photograph demonstrates a high-resolution separation of the protein spots combined with low background staining.

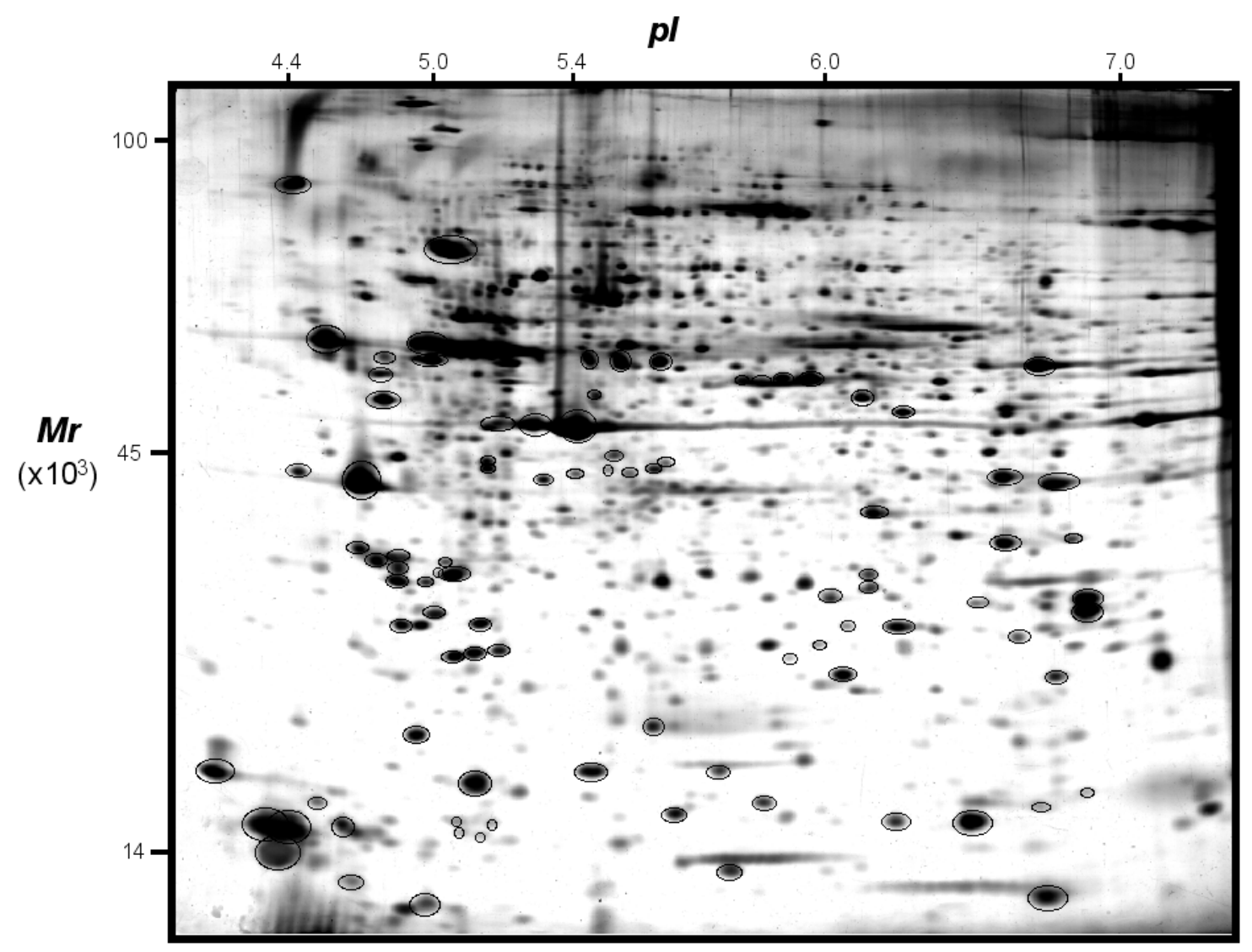

Fig. 1. Mytilus galloprovincialis. Representative 2-dimensional gel electrophoresis of silver-stained proteins from foot. Average of 750 spots was detected by Melanie 3 software. Circles indicate the 92 proteins selected for further quantitative study. Mr: apparent molecular mass; pI: isoelectric points 

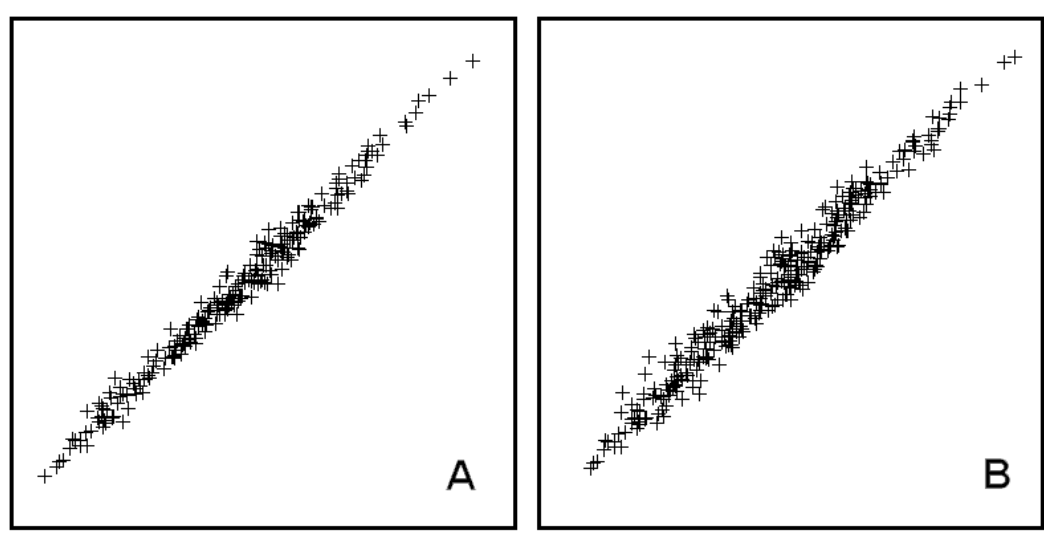

Fig. 2. Mytilus galloprovincialis. Scatter plots comparing reproducibility of protein intensity. Computer-analysed data from the same sample run on 2 separate gels ( $x$-axis vs $y$-axis). (A) Same sample side by side; (B) same sample at different times

Using the spot-finding protocol of the Melanie 3 software, an average of 750 spots per gel was detected in 8 individuals ( 4 from the intertidal population and 4 from the cultured population). Several gels per individual were run but, given the reproducibility of the spots in gels, only 1 gel per individual was used for computer analysis.

To assess the quantitative reproducibility of the protein spots in the gels, 2 series of 3 runs each were performed. Firstly, the same mussel protein extract was run on 2 separate gels side by side under identical conditions. Secondly, the same sample was run on 2 separate gels but on different days. Mean values of the correlation coefficient among spots between gels were $0.988 \pm 0.011$ in the first and $0.981 \pm$ 0.013 in the second series, clearly showing a high reproducibility. Fig. 2 shows examples of these 2 series of assays as scatter plots in which each protein is plotted according to its intensity ( $\%$ vol) in the first gel ( $x$-axis) versus its intensity in the second gel (y-axis). This type of plot is useful because it displays both the deviations from a ratio of 1 and the intensity of each spot. It can be seen that the points from duplicate gels were tightly clustered about the diagonal. In addition, to exclude any artefact as a consequence of silver-staining, the same process was performed using Coomassie blue staining as a control and similar results were obtained (data not shown).

\section{Protein changes in intertidal and cultured mussels}

To compare protein expression between mussels from the intertidal and cultured populations, 92 sharp spots, i.e. those that were non-ambiguous and detected in all samples, were chosen from the gels (Figs $1 \& 3$ ). Spots in crowded areas or around the edges and spots with extremely high or low intensities were discarded. Protein spots that were unique for an individual were also discarded, i.e. qualitative changes.

Statistically significant differences in protein intensity (\%vol) between intertidal and cultured mussels were detected in 45 of these 92 spots $(48.9 \%)$ by means of the non-parametric MannWhitney $U$-test $(p<0.05)$. In 31 of these proteins, expression was higher in the cultured than in the intertidal mussels, while in the other 14 protein spots, intensities were higher in the intertidal mussels (Fig. 3). On the other hand, statistically significant differences were not detected in the remaining $47(51.1 \%)$ spots.

Table 1. Mytilus galloprovincialis. Sequence of peptides determined by nESI-ITmass spectrometry. By this method, the amino acids I and L, K and Q, and F and the oxidised form of $M$ have the same mass and therefore are indistinguishable. For simplicity, only the first member of each isobaric pair is indicated, unless a full sequence identity was found with a protein present in the database. However, since peptides are generated by trypsin in conditions under which almost complete digestion would be expected, K should be present instead of $\mathrm{Q}$ at the $\mathrm{C}$-terminal position, and $\mathrm{Q}$ is more probable than $\mathrm{K}$ in internal positions. Numbers in parentheses: accession numbers of the proteins in Swissprot database

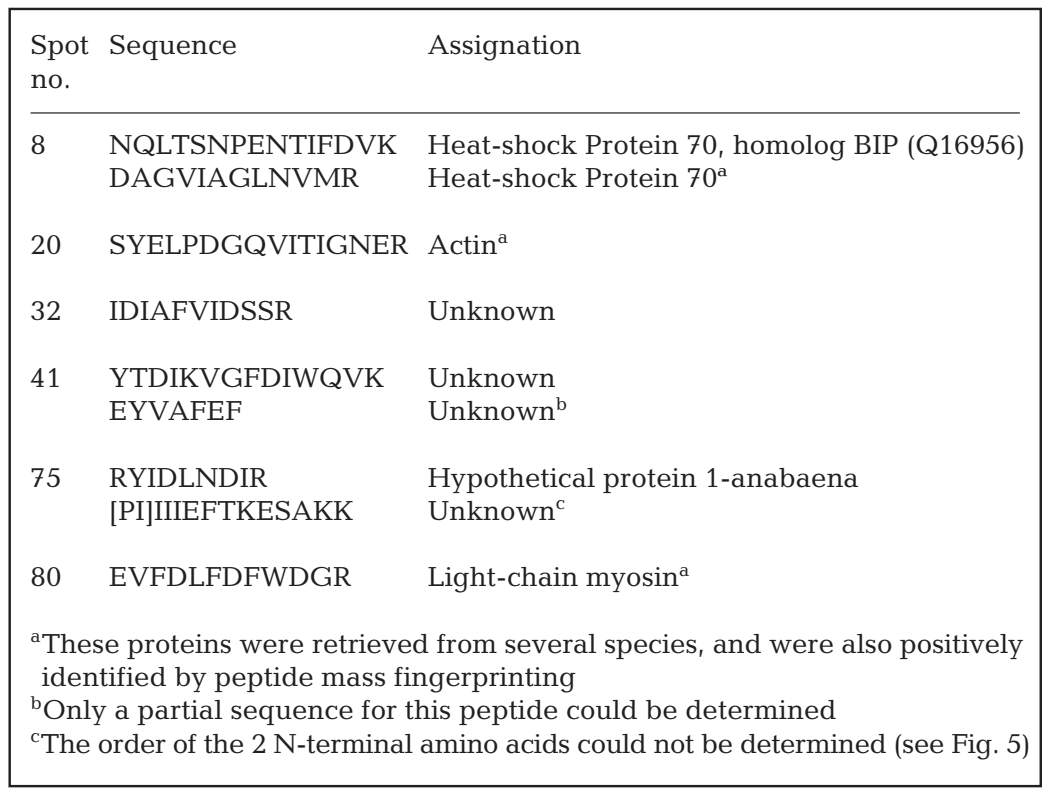




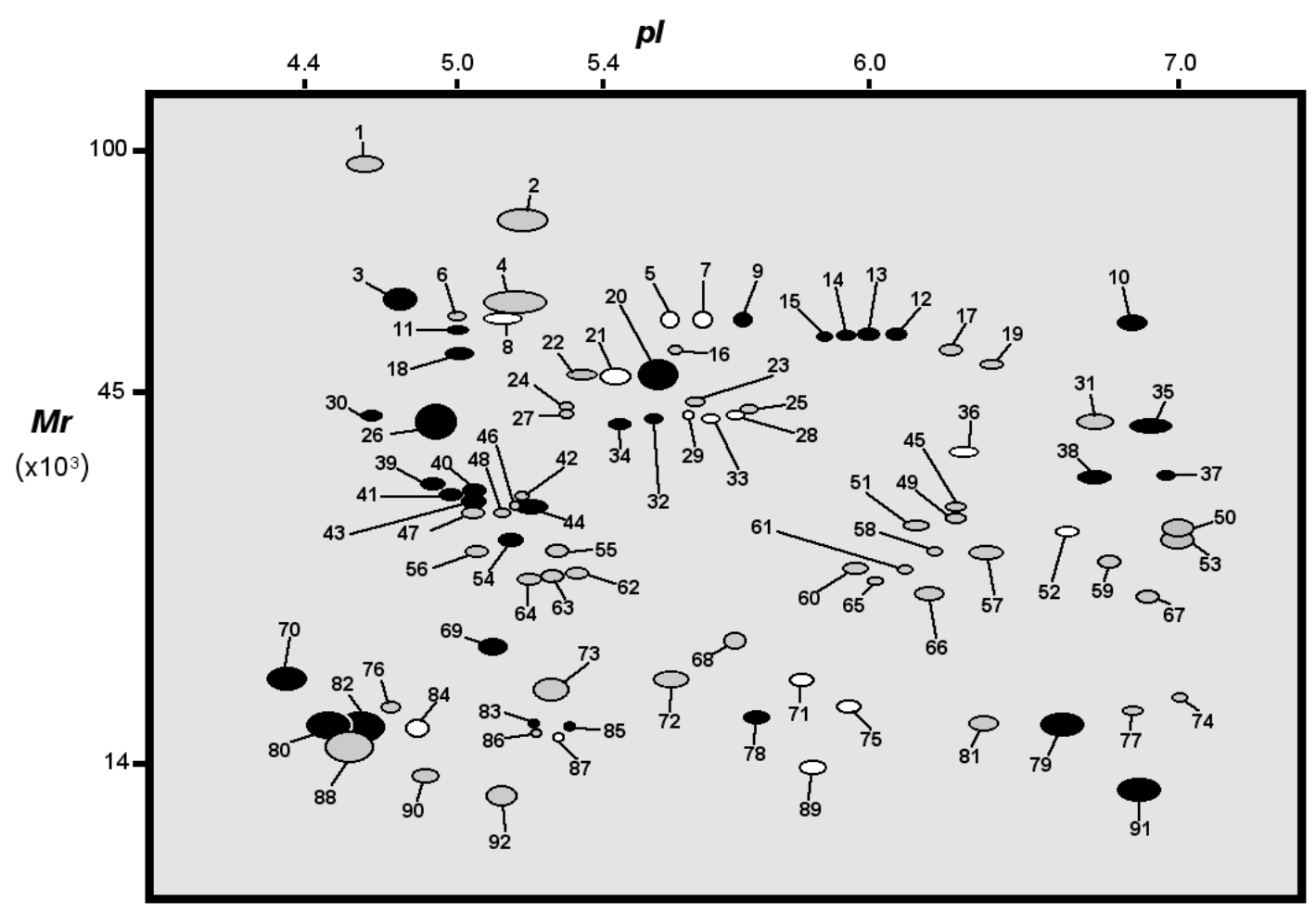

Fig. 3. Mytilus galloprovincialis. Two-dimensional gel electrophoresis schematic map showing all proteins (numbered) analysed (see Fig. 1). Circles/ellipses represent quantitative protein expression: black = increased significantly in cultured stock; white $=$ decreased significantly in cultured population; grey = no significant changes. Mr: apparent molecular mass; pI: isoelectric points

Fig. 4 shows the mean intensity of those spots with the greatest difference (2-, 3-, or 4 -fold greater) between intertidal and cultured mussels (Spots 8, 20, 32, 41, 75 and 80). These 6 proteins were analysed by mass spectrometry. Proteins corresponding to Spots 8, 20 and 80 were positively identified by peptide mass fingerprinting as Heat-shock Protein 70, light-chain myosin protein and actin, respectively. These 3 proteins were identified in several species, demonstrating that in some cases conserved sequence homology may
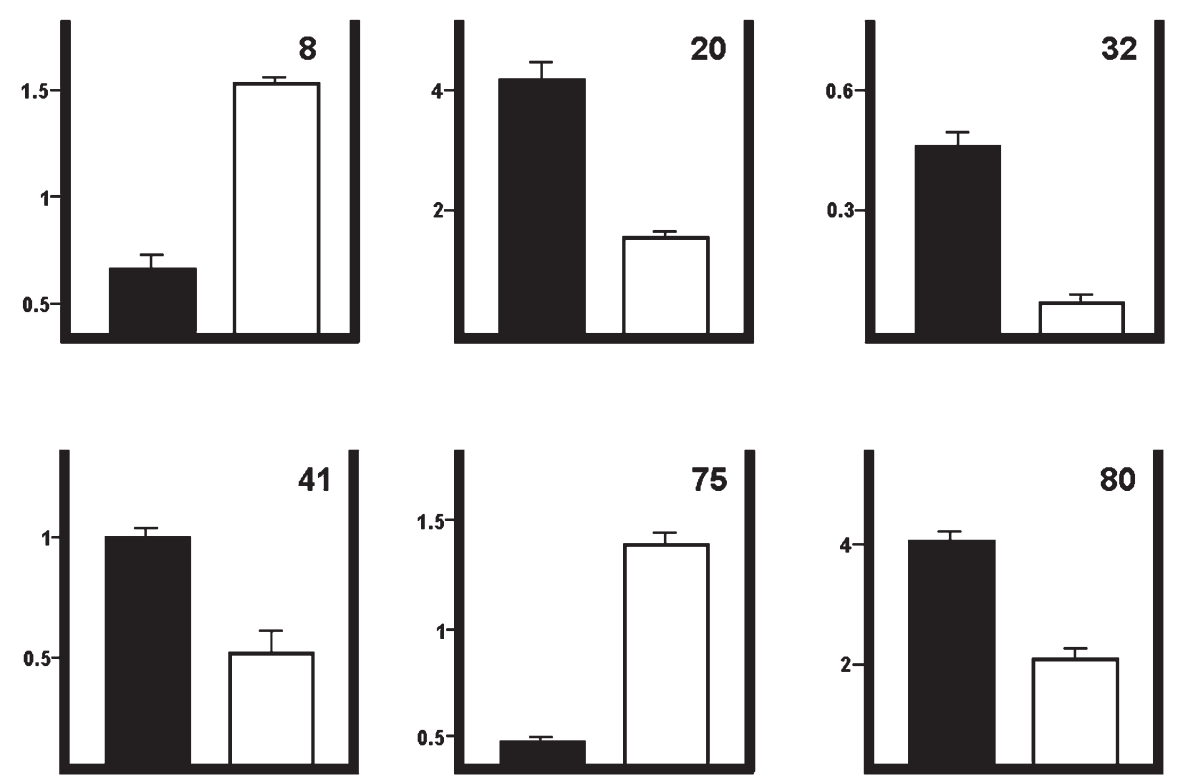

Fig. 4. Mytilus galloprovincialis. The 6 proteins (Nos. 8, 20, 32, 41, 75, 80) displaying greatest difference in relative abundance of protein between intertidal and cultured mussels. Black bars: means (+SEM) of 4 gels from cultured population. White bars: means (+SEM) of 4 gels from intertidal population. Values are in \% vol 
suffice for fast protein identification in species not actually present in databases. The identity of these 3 proteins was confirmed by MS/MS analysis (Table 1) of at least 1 peptide per protein. All the MS/MS spectra gave a positive database match. One of the sequenced peptides did not correspond exactly to a heat-shock protein, but to a protein showing high homology and belonging to the same family. Our data did not allow us to discern whether Spot 8 corresponded to the stress-induced isoform (hsp70) or the constitutively expressed cognate (hsc70).

In contrast, peptide mass fingerprinting alone did not result in identification of the other 3 selected spots. Since good-quality MS/MS spectra could be obtained from some of the peptides derived from digestion of these spots, a database search using selected MS/MS spectra was performed; however a positive match was obtained in 1 case only (Table 1). The remainder of the spectra was therefore subjected to 'de novo' sequence interpretation, as exemplified in Fig. 5, and the sequences obtained are shown in Table 1. No significant sequence homology could be deduced from these sequences, and the sequence of the second peptide of Spot 75 did not show any sequence similarity with the protein identified in the database using the MS/MS spectrum from the first peptide. Also, we could not determine the exact sequence order of the $2 \mathrm{~N}$-terminal amino acids for one of the peptides, and only partial sequence information could be obtained for another (Table 1). These results are illustrative of the inherent complexity of identifying proteins by mass spectrometry in species not present in databases.

\section{DISCUSSION}

In the present study, high-resolution 2-DE was used for the quantitative analysis of the proteins of the

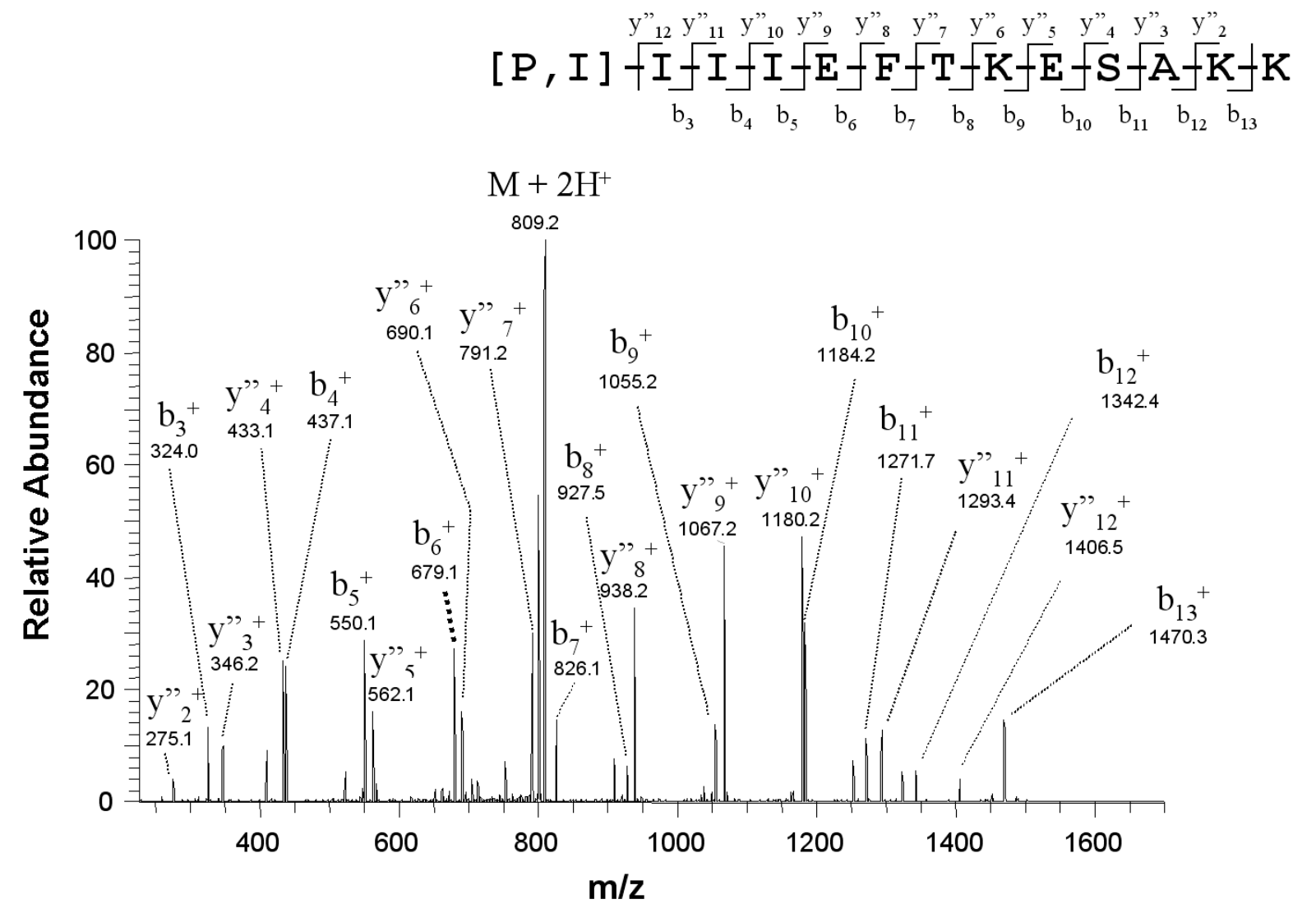

Fig. 5. Mytilus galloprovincialis. Sequencing of one of the peptides generated from Spot 75 by nESI-IT mass spectrometry, showing the fragment MS/MS spectrum from the ion species at $\mathrm{m} / \mathrm{z} 808.9\left(\mathrm{M}+2 \mathrm{H}^{+}\right)$, which corresponds to a peptide with $\mathrm{m} / \mathrm{z} 1616.8$ $\left(\mathrm{M}+\mathrm{H}^{+}\right)$. Assigned peptide sequence is indicated, detailing the observed backbone fragment ions according to nomenclature of Roepstorff \& Fohlmann (1984). Note that the only combination of amino acids which matches the fragment spectrum at the N-terminal end is P plus I; however, it was not possible to determine the order of succession of these 2 amino acids and they are therefore presented in brackets. For simplicity, we present only 1 of the possible amino acids in each of the 3 isobaric pairs (see legend to Table 1) 
mussel Mytilus galloprovincialis and experimental conditions for performing 2-DE of the foot proteins of the mussels were established. When all experimental conditions were properly defined and perfectly adjusted, gels with high-resolution separation of the protein spots and low background staining were obtained.

The foot of this mollusc was the tissue of choice for several reasons. Preliminary experiments have shown that 2-DE gels from the foot of the mussel have better resolution than those from other tissues such as the mantle, branchia and digestive gland. The mantle is subject to important seasonal changes in protein expression because of the gametogenic cycle, while the digestive gland and the branchia can present contaminating exogenous proteins. However, the foot is free from these problems, and therefore ideal for this type of analysis.

Reliable data were obtained from the complex images of 2-DE gels by performing previous calibrations of the scan device and using Melanie 3 software for data analysis (Appel et al. 1991, Hochstrasser et al. 1991, Tsuji et al. 1999). Because factors such as protein extraction, freezing and thawing of samples and gel staining could influence the results (Dunn 1987, Klose \& Kobalz 1995) an analysis of quantitative reproducibility was performed. The results showed that the technique is consistently reproducible and reliable for comparative studies (Fig. 2). An identical approach has also been applied to other species (Higginbotham et al. 1991, Heinke et al. 1998, Tsuji et al. 1999, Vasseur et al. 1999) and similar results were obtained.

The resolution power of the 2-DE technique allows for detection of an extensive number ( 800) of proteins in a single run, unlike conventional electrophoresis methods, which detect much fewer proteins. In this work, an average of 750 foot proteins was detected in all analysed samples in a reproducible way (Fig. 1).

Comparison of the 2 mussel populations (intertidal and cultured) revealed statistically significant differences in protein intensity in nearly half the spots (45 spots out of 92 analysed). This result is consistent with the high sensitivity of the 2-DE technique and with what would be expected from populations growing in 2 very different ecological environments (see 'Materials and methods'). While intertidal mussels live in a very stressful environment, with permanent and cyclic changes of temperature, air exposure, food availability, etc., raft-cultivated mussels grow in a much more stable environment. As demonstrated by Labarta et al. (1997), mussels adapt to both environments by altering their physiological behaviour, with cultured mussels having a higher clearance rate, absorption efficiency and ammonia excretion rate than intertidal mussels. Therefore, differences in protein expression, resulting from the different physiological adaptations should be expected between the 2 types of mussels.

Because mussels are poorly characterised at the 'proteome' level in protein database searches, we were able to identify only 3 of the 6 spots analysed by mass spectrometry. The higher levels of the cytoskeletal proteins actin and myosin in the cultured compared to the intertidal mussels are difficult to explain. However, the higher levels of Heat-shock Protein 70 detected in the intertidal mussels could be a molecular response to the changes in temperature that these mussels undergo during low tide. The major property of Heat-shock Protein 70 is its chaperonic activity and its functions are to protect cells from environmental stress damage by binding to partially denatured proteins, to dissociate protein aggregates, to regulate correct folding, and to cooperate in transporting newly synthesised polypeptides to target organelles (Sarto et al. 2000). Ecological analyses of levels of Heat-shock Protein 70 for determining biological pollution in Mytilus species are numerous, and are used as a biochemical index of thermal damage to cellular proteins and for studying environmental adaptation and thermal tolerance (Hofmann \& Somero 1996, Roberts et al. 1997, Chapple et al. 1998).

Acknowledgements. J.L.L. is very grateful to Dr Ronald S. Oosting for his valuable comments and suggestions, which greatly improved this manuscript. He is also grateful to Dr Ian Humphery-Smith for advising us on this topic. This research was supported by a grant from the Xunta de Galicia (Spain) to G.A.

\section{LITERATURE CITED}

Anderson NG, Anderson L (1998) Proteome and proteomics: new technologies, new concepts, and new words. Electrophoresis 19:1853-1861

Appel RD, Hochstrasser DF, Funk M, Vargas JR, Pellegrini C, Muller AF, Scherrer JR (1991) The MELANIE project: from a biopsy to automatic protein map interpretation by computer. Electrophoresis 12:722-735

Bradford MM (1976) A rapid and sensitive method for the quantitation of microgram quantities of protein utilizing the principle of protein-dye binding. Anal Biochem 72: $248-254$

Byrjalsen I, Mose Larsen P, Fey SJ, Nilas L, Larsen MR, Christiansen C (1999) Two-dimensional gel analysis of human endometrial proteins: characterization of proteins with increased expression in hyperplasia and adenocarcinoma. Mol Human Reprod 5:748-756

Chapple JP, Smerdon GR, Berry RJ, Hawkins AJS (1998) Seasonal changes in stress-70 protein levels reflect thermal tolerance in the marine bivalve Mytilus edulis L. J Exp Mar Biol Ecol 229:53-68

Dunn MJ (1987) Advances in electrophoresis. In: Chrambach A, Dunn MJ, Radola BJ (eds) Two-dimensional polyacrylamide gel electrophoresis, Vol 1. VCH, Weinheim, p 4-109

Fuentes J, Gregorio V, Giráldez R, Molares J (2000) Withinraft variability of the growth rate of mussels, Mytilus gal- 
loprovincialis, cultivated in the Ría de Arousa (NW Spain). Aquaculture 189:39-52

Goldberg ED (1975) The Mussel Watch. A first step in global marine monitoring. Mar Pollut Bull 6:11

Heinke MY, Wheeler CH, Chang D, Einstein R, Drake-Holland A, Dunn MJ, dos Remedios CG (1998) Protein changes observed in pacing-induced heart failure using twodimensional electrophoresis. Electrophoresis 19:2021-2030

Hickman RW (1992) Mussel cultivation. In: Gosling E (ed) The mussel Mytilus: ecology, physiology, genetics and culture. Elsevier, Amsterdam, p 465-504

Higginbotham JW, Smith JS, Smith OS (1991) Quantitative analysis of two-dimensional protein profiles of inbred lines of maize (Zea mays L). Electrophoresis 12:425-431

Hochstrasser DF (1998) Proteome in perspective. Clin Chem Lab Med 36:825-836

Hochstrasser DF, Appel RD, Vargas R, Perrier, R, Vurlod JF, Ravier F, Pasquali C, Funk M, Pellegrini C, Muller AF, Scherrer JR (1991) A clinical molecular scanner: the Melanie project. MD Comput 8:85-91

Hofmann GE, Somero GN (1996) Interspecific variation in thermal denaturation of proteins in the congeneric mussels Mytilus trossulus and M. galloprovincialis: evidence from the heat-shock response and protein ubiquitination. Mar Biol 126:65-75

Humphery-Smith I, Cordwell SJ, Blackstock WP (1997) Proteome research: complementarity and limitations with respect to the RNA and DNA worlds. Electrophoresis 8: $1217-1242$

Jungblut PR, Zimny-Arndt U, Zeindl-Eberhart E, Stulik J and 8 others (1999) Proteomics in human disease: cancer, heart and infectious diseases. Electrophoresis 20:2100-2110

Klose J, Kobalz U (1995) Two-dimensional electrophoresis of proteins: An updated protocol and implications for a functional analysis of the genome. Electrophoresis 16: 1034-1059

Konecny P, Redinbaugh MG (1997) Amplification of differentially displayed PCR products isolated from untreated denaturing polyacrylamide gels. Biotechniques 22:240-242

Labarta U, Fernández-Reiríz MJ, Babarro JMF (1997) Differences in physiological energetics between intertidal and raft cultivated mussels Mytilus galloprovincialis. Mar Ecol Prog Ser 152:167-173

Marina A, Garcia MA, Albar JP, Yague J, Lopez de Castro JA, Vazquez J (1999) High-sensitivity analysis and sequenc-

Editorial responsibility: Otto Kinne (Editor), Oldendorf/Luhe, Germany ing of peptides and proteins by quadrupole ion trap mass spectrometry. J Mass Spectrom 34:17-27

Morrissey JH (1981) Silver stain proteins in polyacrylamide gels: a modified procedure with enhanced uniform sensitivity. Anal Biochem 117:307-310

O'Farrell PH (1975) High resolution two-dimensional electrophoresis of proteins. J Biol Chem 250:4007-4021

Pérez Camacho A, González R, Fuentes J (1991) Mussel culture in Galicia (N.W. Spain). Aquaculture 94:263-278

Ramagli LS, Rodríguez LV (1985) Quantitation of microgram amounts of protein in two-dimensional polyacrylamide gel electrophoresis sample buffer. Electrophoresis 6:559-563

Roberts DA, Hofmann GE, Somero GN (1997) Heat-shock protein expression in Mytilus californianus: acclimatization/seasonal and tidal-height comparisons) and acclimation effects. Biol Bull 192:309-320

Roepstorff P, Fohlmann J (1984) Proposal for a common nomenclature for sequence ions in mass spectra of peptides. Biomed Mass Spectrom 11:601

Sanjuan A, Quesada H, Zapata C, Alvarez G (1990) On the occurrence of Mytilus galloprovincialis Lmk on the N.W. coast of the Iberian Peninsula. J Exp Mar Biol Ecol 143: $1-14$

Sanjuan A, Zapata C, Alvarez G (1994) Mytilus galloprovincialis and $M$. edulis on the coasts of the Iberian Peninsula. Mar Ecol Prog Ser 113:131-146

Santarén JF, García-Bellido A (1990) High-resolution twodimensional gel analysis of proteins in wing imaginal dics: a data base of Drosophila. Exp Cell Res 189:169-176

Sarto C, Binz PA, Mocarelli P (2000) Heat shock proteins in human cancer. Electrophoresis 21:1218-1226

Shevchenko A, Wilm M, Vorm O, Mann M (1996) Mass spectrometric sequencing of proteins silver-stained polyacrylamide gels. Anal Chem 68:850-858

Suchanek TH (1985) Mussels and their role in structuring rocky shore communities. In Moore PG, Seed R (eds) The ecology of rocky coasts. Hodder \& Stoughton, Sevenoaks, p 70-96

Tsuji T, Shimohama S, Kamiya S, Sazuka T, Ohara O (1999) Analysis of brain proteins in Alzheimer's disease using high-resolution two-dimensional gel electrophoresis. J Neurol 166:100-106

Vasseur C, Labadie J, Hebraud M (1999) Differential protein expression by Pseudomonas fragi submitted to various stresses. Electrophoresis 20:2204-2213

Submitted: November 16, 2000, Accepted: April 12, 2001 Proofs received from author(s): November 30, 2001 